\title{
Analisis Dampak Keterkaitan dan Pengganda sebagai Identifikasi Lever Sector (Pendekatan Tabel Input-Output 2020 Estimasi)
}

\author{
(Linkage Effect and Multiplier Analysis for Identifying Lever Sector (Input-Output Table Approach \\ 2020 Estimation)
}

Yoga Dwi Nugroho

Badan Pusat Statistik (BPS-RI)

Email:yogadwinugroho26@gmail.com

\begin{abstract}
ABSTRAK
Pembangunan ekonomi berbasis sektor harus dilakukan dengan menggunakan indikator ekonomi yang komprehensif, tidak hanya melihat struktur ekonomi saja tetapi mampu mengidentifikasi dan menganalisis hubungan antar kegiatan ekonomi (inter-industry relationship). Salah satu indikator yang tepat adalah melalui analisis Tabel Input-Output. Tabel I-O semakin banyak digunakan khususnya untuk keperluaan analisis dan perencanaan, tidak terkecuali oleh pemerintah atau decision maker dalam perencanaan pembangunan ekonomi suatu wilayah berbasis sektor serta dapat menganalisis berbagai fenomena ekonomi yang multisektor. Penelitian ini menggunakan Tabel I-O Tahun 2020 yang diestimasi dari tabel I-O tahun 2016. Dalam analisis komprehensif ini akan dihitung Forwad dan Backward Linkage Index sehingga dapat diidentifikasi sektor yang masuk dalam sektor pengungkit. Selain itu, dilakukan analisis pengganda baik, output, income, labor dan value added multiplier untuk melihat besaran pengganda yang ditimbulkan akibat perubahan permintaan akhir. Hasil penelitian sektor yang masuk sebagai sektor pengungkit atau Lever sector adalah sektor industri pengolahan (sektor 3) yang merupakan sektor dengan struktur output, nilai tambah dan input yang besar, serta memiliki multiplier yang tinggi untuk empat jenis multiplier dan analisis keterkaitan Forwad dan Backward Linkage Index yang tinggi nilainya.
\end{abstract}

Kata kunci: Pembangunan Ekonomi, Tabel Input Output, Forward dan Backward Linkage, Analisis Pengganda, Lever Sector

\begin{abstract}
Sector-based economic development must be carried out using comprehensive economic indicators, not only looking at the economic structure but also being able to identify and analyze inter-industry relationships. One of the right indicators is through the analysis of the Input-Output Table. The use of I-O Tables as quantitative models, both for analysis and planning purposes, is increasingly in demand by many parties, including the government or decisionmakers in planning the economic development of a sector-based region and being able to analyze various multisectoral economic phenomena. The I-O table used is the $2020 \mathrm{I}-\mathrm{O}$ table which is estimated from the $2016 \mathrm{I}-\mathrm{O}$ table. In this comprehensive analysis, the Forward and Backward Linkage Index will be calculated so that the sectors that are included in the Lever sector can be identified. In addition, a good multiplier analysis is carried out, output, income, labor, and value-added a multiplier to see the amount of multiplier caused by changes in final demand. The results of the research shows that sector that is included as a lever sector is the manufacturing sector (sector 3) which is a sector with a large output, added value and input structure, and has a high multiplier for four types of multipliers and analysis of Forwad linkages and Backward Linkage Index shows this sector has high value.
\end{abstract}

Keywords: Economic Development, Input Output Tables, Forward and Backward Linkage, Multiplier Analysis, Lever Sector

\section{PENDAHULUAN}

Pembangunan ekonomi merupakan proses adanya perubahan dalam struktur ekonomi, kemiskinan, pengangguran, ketimpangan dan lain sebagainya (Todaro dan Smith, 2011). Lebih lanjut lagi, Dunford (2009) menjelaskan bahwa pembangunan ekonomi regional tergantung pada ketersediaan sumber daya, yang merupakan rangkaian kegiatan yang berasal dari manusia (tenaga kerja), akumulasi modal, penggunaan teknologi modern, dan output. Pembangunan ekonomi yang baik dapat dilaksanakan dengan melihat struktur ekonomi dan potensi sumber daya yang ada, salah satu hal mudah dengan melihat struktur ekonomi suatu wilayah melalui Produk Domestik Bruto (PDB). Data PDB menurut lapangan usaha atau produksi Indonesia tahun 2020 (Gambar 1) menunjukkan bahwa sektor dengan kontribusi tertinggi adalah sektor industri pengolahan dengan 21,39 persen, sektor perdagangan besar dan eceran dengan 13,42 persen, sektor 
pertanian, kehutanan, dan perikanan sebesar 13, 34 persen serta sektor konstruksi dengan 10,38 persen. Keempat sektor inilah yang diduga merupakan sektor yang potensial untuk peningkatan dan pengembangan ekonomi dalam melaksanakan pembangunan ekonomi yang baik. Di sisi lain, keadaan pandemi Covid-19 yang menyerang seluruh negara di dunia tidak terkecuali Indonesia menyebabkan perekonomian juga terdampak. Pada akhir tahun 2020 kasus Covid-19 di Indonesia mencapai 664.930 kasus dengan kasus meninggal mencapai 19.880 orang dan kasus ini semakin bertambah sampai saat ini. Keadaan ini menyebabkan sektor-sektor penting collapse sehingga kondisi ekonomi juga semakin buruk. Data yang dirilis Badan Pusat Statistik pertumbuhan ekonomi secara kumulatif (c-to-c) mengalami kontraksi 2,07 persen dan Indonesia terjebak resesi sepanjang tiga kuartal yaitu, pertumbuhan ekonomi kuartal II 2020 mengalami kontraksi 5,32 persen, kuartal III mengalami kontraksi 3,49 persen dan kuartal IV mengalami kontraksi 2,19 persen. Di sisi lain, tahun 2020 inflasi Indonesia sebesar 1,68 persen yang merupakan nilai inflasi terendah dalamsejarah. Kondisi ini menunjukkan lemahnya perputaran uang dan lesunya aktivitas ekonomi di Indonesia. Kondisi yang sulit ini juga menciptakan peningkatan angka pengangguran yang mencapai 2,56 juta orang selama pandemic Covid-19. Kondisi ini menyebabkan pemerintah harus menyusun strategi untuk pemulihan ekonominya, salah satunya melalui analisis sektor pengungkit.

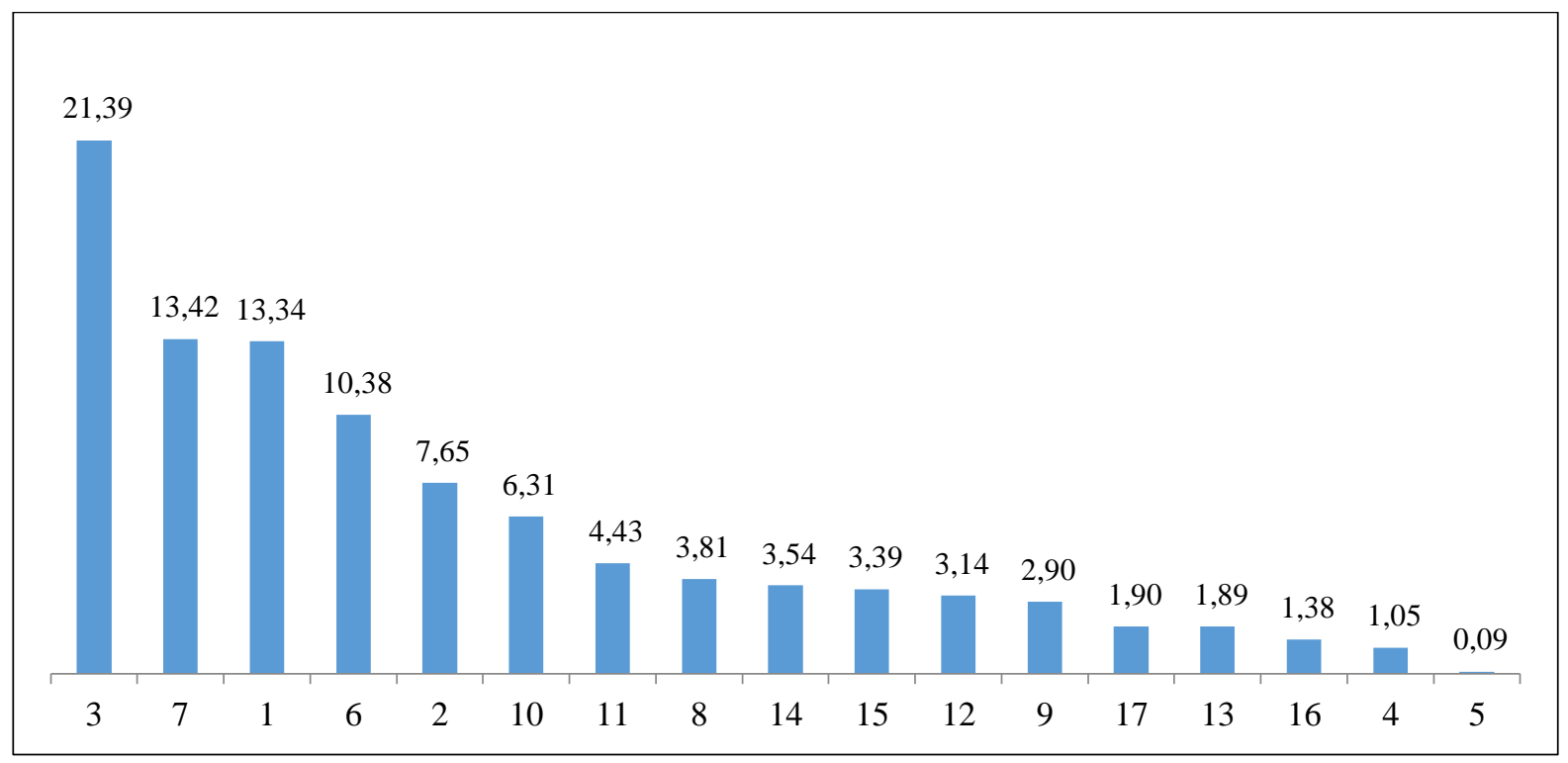

Sumber: www.bps.go.id (diolah)

Gambar 1. Struktur Ekonomi Indonesia menurut PDB Lapangan Usaha, Tahun 2020 (diurutkan menurut persen share terbesar)

\section{Keterangan:}

1: Pertanian, Kehutanan, dan Perikanan

2: Pertambangan dan Penggalian

3: Industri Pengolahan

4: Pengadaan Listrik, Gas

5: Pengadaan Air, Pengelolaan Sampah, Limbah dan

...Daur Ulang

6: Konstruksi

7: Perdagangan Besar dan Eceran, Reparasi Mobil dan

... Sepeda Motor

8: Transportasi dan Pergudangan

9: Penyediaan Akomodasi dan Makan Minum

10: Informasi dan Komunikasi

\author{
11: Jasa Keuangan dan Asuransi \\ 12: Real estate \\ 13: Jasa Perusahaan \\ 14: Administrasi Pemerintahan, Pertahanan dan \\ ....Jaminan Sosial Wajib \\ 15: Jasa Pendidikan \\ 16: Jasa Kesehatan dan Kegiatan Sosial \\ 17: Jasa lainnya
}

Namun untuk menentukan sektor potensial/unggulan atau yang selanjutnya dapat disebut sebagai sektor pengungkit atau Lever sector diperlukan indikator ekonomi lain yang tidak hanya menunjukkan struktur ekonomi saja, namun secara komprehensif juga dapat menjelaskan keterkaitan antar sektor dan efek pengganda yang ditimbulkan akibat aktivitas ekonomi sektor tersebut. Badan Pusat Statistik (2021) menjelaskan bahwa pembangunan sektor-sektor ekonomi tidak hanya bertumpu pada informasi kontribusi sektor tersebut terhadap perekonomian tetapi juga melihat keterkaitan suatu sektor dengan sektor lainnya. 
Keterkaitan ini ditunjukkan dengan tingkat kemampuan suatu sektor untuk menggerakkan roda perekonomian. Adapun alat/indikator ekonomi tersebut dapat diidentifikasi melalui analisis tabel InputOutput Miyazawa. Lebih lanjut, data yang disajikan pada tabel Input-Output Miyazawa dapat dimanfaatkan untuk melakukan analisis dan proyeksi perekonomian dalam perencanaan pembangunan. Penggunaan Tabel I-O sebagai model kuantitatif, baik untuk keperluan analisis maupun perencanaan semakin diminati oleh banyak pihak, tidak terkecuali oleh pemerintah atau decision maker dalam perencanaan pembangunan ekonomi suatu wilayah berbasis sektor serta dapat menganalisis berbagai fenomena ekonomi yang multisektor. Lebih lanjut lagi dalam suatu kegiatan perekonomian terjadi keterkaitan antar sektor yang semakin dinamis dan kuat. Suatu sektor dapat maju dikarenakan ada dukungan dari sektor-sektor yang lain. Begitu juga sebaliknya, ketika suatu sektor meredup bahkan menghilang akan mengakibatkan dampak yang kurang baik terhadap sektor lain. Adanya hubungan antar kegiatan ekonomi ini (inter-industry relationship) dapat dijelaskan oleh model Input-Output (I-O) Miyazawa. Adapun tabel I-O yang tebaru adalah tabel I-O tahun 2016, maka untuk menyesuaikan dengan kondisi ekonomi yang terkini perlu dilakukan adjustment atau estimasi.

Penelitian dengan menggunakan Tabel I-O Miyazawa ini sudah dilakukan oleh Malba dan Taher (2016) yang ingin meninjau dampak dari sektor pariwisata terhadap perekonomian di Maluku, Amir dan Nazara (2005) menggunakan tabel I-O untuk menganalisis perubahan struktur ekonomi serta meninjau kebijakan strategi yang diaplikasikan dalam pembangunan ekonomi di Jawa Timur, Sapanli et al (2020) menggunakan tabel I-O untuk menganalisis dinamika dan kebijakan pengembangan ekonomi kelautan di Indonesia serta Widyawati (2017) yang mengidentifikasi keterkaitan sektor pertanian dan pengaruhnya terhadap perekonomian Indoensia. Adapun tujuan dari penelitian ini adalah melakukan estimasi tabel Input-Output Miyazawa Tahun 2020, Menganalisis dampak (backward and forward linkage) dan pengganda (multiplier analysis) yang meliputi output, income, labor dan value added multiplier sebagai identifikasi Lever sector.

\section{METODOLOGI}

\section{Data dan Sumber Data}

Adapun data yang digunakan dalam penelitian ini bersumber dari publikasi dan tabel dinamis yang telah dipublikasikan oleh Badan Pusat Statistik. Adapun data dan variabel yang dikumpulkan adalah sebagai berikut:

1. Tabel Input-Output Miyazawa Tahun 2016, 17x17 sektor

2. Produk Domestik Bruto (PDB) menurut lapangan usaha atau produksi ADHK, Tahun 20162020

3. Tenaga Kerja menurut lapangan usaha Tahun 2016-2020

4. Rata-rata upah gaji buruh/karyawan menurut lapangan usaha Tahun 2016-2020

\section{Struktur Tabel I-O Miyazawa dan Estimasi Tabel I-O Tahun 2020}

Badan Pusat Statistik (2021) menjelaskan bahwa Tabel I-O menyajikan informasi mengenai transaksi barang maupun jasa yang terjadi antar sektor ekonomi yang penyajiannya berupa matriks. Nilai pada baris Tabel I-O menunjukkan adanya pengalokasian output yang dihasilkan oleh suatu sektor tertentu untuk memenuhi permintaan antara dan permintaan akhir. Di samping itu, nilai pada baris nilai tambah menjelaskan komposisi penmbentukan nilai tambah sektoral. Untuk isian sepanjang kolomnya menunjukkan struktur input yang digunakan oleh masing-masing sektor dalam proses produksi, baik berupa input antara maupun input primer. Asumsi dasar dalam penyusunan Tabel I-O adalah keseragaman, kesebandingan dan penjumlahan.

Tabel I-O Miyazawa dibagi menjadi tiga kuadran dimana kuadran I merupakan transaksi antara, yaitu transaksi barang dan jasa yang digunakan dalam proses produksi, kuadran inilah yang menunjukkan keterkaitan antar sektor ekonomi di dalam proses produksi. Kuadran II menunjukkan permintaan akhir, isian sepanjang baris memperlihatkan komposisi permintaan akhir pada suatu sektor produksi. Sedangkan isian sepanjang kolom menunjukkan distribusi pada masingmasing komponen permintaan akhir. Adapun kuadran III menunjukkan komponen input primer atau nilai tambah. Di sisi lain, nilai tambah terdiri dari kompensasi tenaga kerja, surplus usaha bruto, dan pajak dikurang subsidi lainnya atas produksi. 


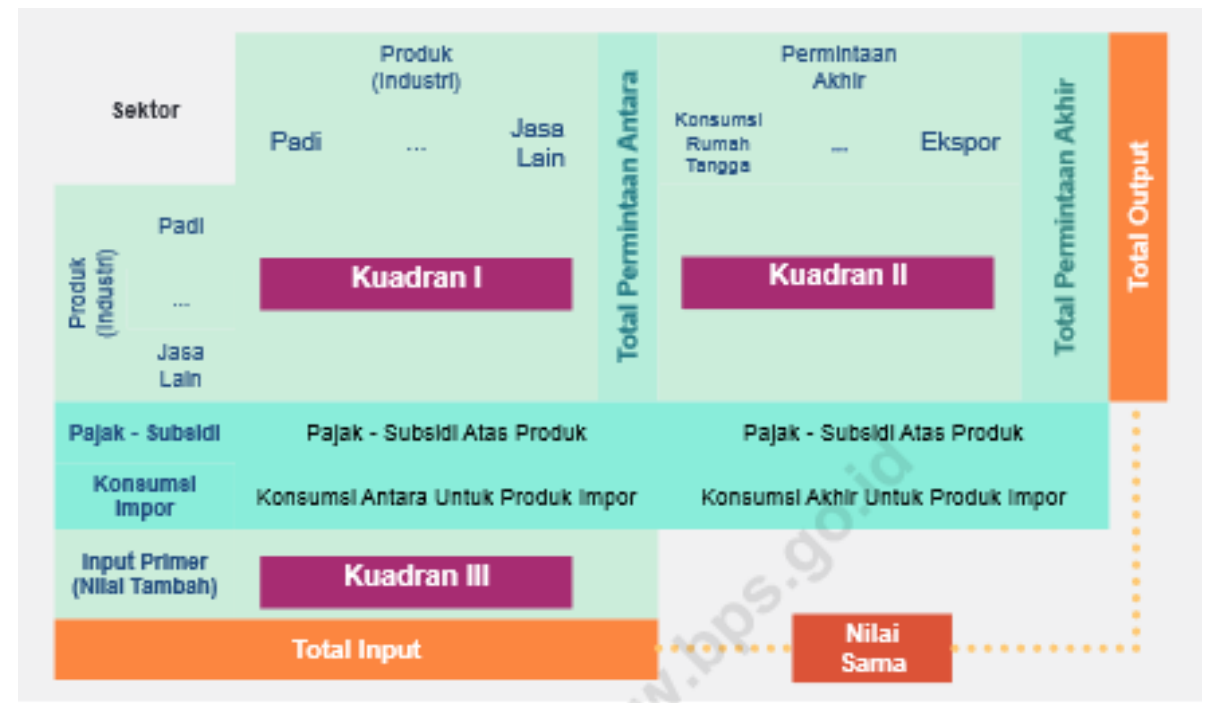

Sumber: $\underline{w w w . b p s . g o . i d}$ (diolah)

Gambar 2. Struktur Tabel I-O Miyazawa

Adapun proses estimasi Tabel I-O Tahun 2020 yang dilakukan dalam penelitian ini adalah sebagai berikut:

1. Menghitung struktur input dari Tabel I-O 2016. Dari hasil ini akan didapatkan matriks struktur input yang nantinya akan diterapkan pada Tabel I-O 2020.

2. Menggunakan informasi mengenai pertumbuhan (growth) PDB per lapangan usaha untuk tahun 2017, 2018, 2019 dan 2020 untuk menumbuhkan total input antara dan nilai tambah brutonya.

3. Untuk komponen permintaan akhir menggunakan pertumbuhan (growth) PDB pengeluaran untuk menumbuhkan nilai ouputnya dengan adjustment komponen inventori sebagai komponen penyeimbangnya.

4. Adapun untuk menumpuhkan kompensasi tenaga kerja untuk setiap lapangan usahanya digunakan growth rata-rata upah tenaga kerja per lapangan usaha atau 17 sektor lapangan usaha sesuai dengan lapangan usaha PDB.

5. Kemudian memeriksa terkait konsistensi dan keseimbangan input dan outputnya. Jika masih tidak seimbang atau unbalance maka dilakukan adjustment supaya komponen input dan output menjadi seimbang.

\section{Analisis Dampak (Forward and Backward Linkage)}

Informasi tentang dampak keterkaitan antar sektor produksi dapat dianalisis menjadi Dampak Keterkaitan Kebelakang (Bakward Linkage) dan Dampak Keterkaitan Kedepan (Forward Linkage). Kedua dampak keterkaitan ini dapat diukur berdasarkan angka indeks Daya penyebaran (IBL) dan Derajat Kepekaan (IFL). IBL menunjukkan perbandingan jumlah dampak terhadap output masing-masing sektor akibat perubahan permintaan akhir suatu sektor terhadap rata-rata dampak seluruh sektor. Jika nilai IBL lebih dari satu artinya secara relatif permintaan akhir dari sektor tersebut dalam merangsang pertumbuhan produksi lebih besar dari rata-rata sektor lainnya. Dapat dikatakan, sektor ini merupakan sektor yang strategis karena memiliki daya dorong yang cukup kuat dalam memacu pertumbuhan ekonomi. Kemudian IFL menunjukkan perbandingan jumlah dampak perubahan permintaan akhir masing-masing sektor perekonomian kepada output suatu sektor terhadap rata-rata dampak seluruh sektor. Jika IFL lebih dari satu, artinya secara relatif sektor tersebut dapat memenuhi permintaan akhir dari sektor lainnya di atas kemampuan rata-rata.

Suatu sektor termasuk Lever sector ketika IFL dan IBLnya lebih dari satu. Adapun formula penghitungan IBL dan IFL adalah sebagai berikut:

$$
I F L_{i}=\frac{\sum_{j=1}^{n} b_{i j}}{\sum_{i=1}^{n} \sum_{j=1}^{n} b_{i j}} n \quad I B L_{j}=\frac{\sum_{i=1}^{n} b_{i j}}{\sum_{i=1}^{n} \sum_{j=1}^{n} b_{i j}} n
$$


Keterangan:

$\mathrm{IFL}_{\mathrm{i}}$ : Index of forward linkage untuk sektor ke-i

$\mathrm{b}_{\mathrm{ij}} \quad$ : elemen dari invers matriks Leontif, baris ke-i dan kolom ke-j

$I B L_{j}:$ Index of backward linkage untuk sektor ke-j

\author{
: jumlah sektor \\ : jumlah sektor pada baris (struktur input) \\ :jumlah sektor pada kolom (struktur \\ permintaan)
}

\section{Analisis Pengganda (Multiplier Analysis)}

Analisis pengganda bertujuan untuk mengukur efek total baik itu pada output, income, labor maupun value added ketika terjadi peningkatan satu unit input pada suatu outpu industri tertentu (UN, 1999). Pribadhi (2019) menjelaskan analisis pengganda berguna untuk mengetahui dampak perubahan variabelvariabel eksogen terhadap perekonomian. Untuk menghitung nilai pengganda maka diperlukan matriks Leontif, persamaan model Leontif I-O dapat ditulis sebagai berikut :

$$
\boldsymbol{X}=(\boldsymbol{I}-\boldsymbol{A})^{-1} \boldsymbol{Y} .
$$

Dimana, X merupakan vektor output, Y merupakan vektor permintaan akhir, I merupakan matriks identitas, A merupakan mariks koefisien input dan $(\mathbf{I}-\mathbf{A})^{-1}$ merupakan matriks invers Leontif. Adapun beberapa formula untuk keempat jenis multiplier adalah sebagai berikut :

Tabel 1. Formula penghitungan keempat jenis multiplier.

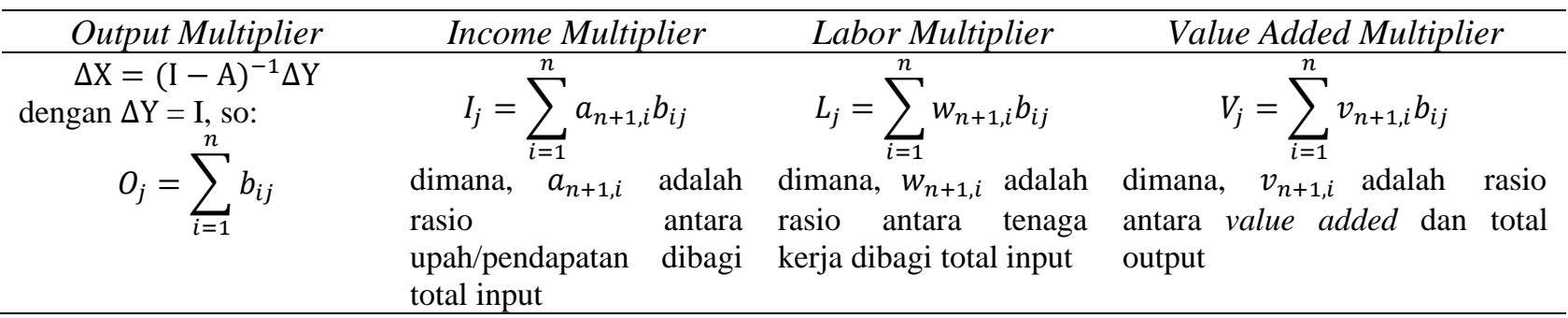

\section{HASIL DAN PEMBAHASAN}

\section{Struktur Tabel I-O (Input Antara, Nilai Tambah dan Output)}

Setelah dilakukan estimasi terkait dengan Tabel I-O Tahun 2020 dengan berpedoman pada struktur input pada Tabel I-O Tahun 2016, maka dapat dianalisis terkait dengan total input antara, nilai tambah dan output dari masing-masing sektor lapangan usaha. Tabel 2 menunjukkan struktur Tabel I-O yang sudah dilakukan estimasi dalam satuan triliun rupiah. Ditinjau dari input antara, nilai tambah dan total outputnya sektor lapangan usaha dengan nilai tertinggi adalah sektor industri pengolahan dengan output mencapai 7.575.443 triliun rupiah atau 28,86 persen dari total keseluruhan output. Adapun sektor kedua dengan nilai output paling tinggi adalah sektor Konstruksi dengan total output mencapai 3.346.728 triliun rupiah atau 12,75 persen dari total keseluruhan total output. Sektor ketiga dan keempat yang tertinggi secara berurutan adalah sektor Perdagangan Besar dan Eceran, Reparasi Mobil dan Sepeda Motor; dan sektor Pertanian, Kehutanan, dan Perikanan dengan masing-masing share terhadap total output mencapai 10,35 persen dan 8,22 persen. Adapun sektor dengan input antara, nilai tambah dan output terendah adalah sektor Pengadaan Air, Pengelolaan Sampah, Limbah dan Daur Ulang dengan nilai output hanya sebesar 65.827 triliun rupiah atau memiliki share sebesar 0,25 persen dari total output.

Di sisi lain, dapat dijelaskan bahwa industri pengolahan membutuhkan sektor lain untuk memasok atau mencukupi inputnya terutama input antara dan perubahan sektor ini di seluruh aspek seperti output, input, atau pendapatan dapat mendorong perubahan sektor lain. Hal ini menunjukkan bahwa multiplier effect dan keterkaitan sektor antara industri pengolahan dan sektor lain secara total lebih tinggi. Di sisi lain, industri pengolahan juga memberikan share tertinggi terhadap PDB secara keseluruhan ekonomi dan memberikan dampak yang signifikan bagi sektor lain jika terjadi perubahan pada sektor ini. Analisis input-output memiliki asumsi bahwa input dan output seimbang sehingga output dalam tabel ini dapat juga disebut input total. Jadi, sektor Industri Pengolahan membutuhkan input terbesar dibandingkan sektor lain yang menunjukkan seberapa besar sektor ini dapat berproduksi. 
Tabel 2. Input Antara, Nilai Tambah dan Output dari 17 Sektor (Triliun Rupiah), Tabel I-O Tahun 2020 (estimasi)

\begin{tabular}{rrrr}
\hline Sektor & Input Antara & Nilai Tambah & Output \\
\hline 1 & 454.528 & 1.702 .185 & 2.156 .712 \\
2 & 388.420 & 895.489 & 1.283 .909 \\
3 & 4.634 .342 & 2.941 .101 & 7.575 .443 \\
4 & 568.643 & 159.772 & 728.416 \\
5 & 20.792 & 45.035 & 65.827 \\
6 & 2.037 .119 & 1.309 .609 & 3.346 .728 \\
7 & 786.698 & 1.929 .600 & 2.716 .298 \\
8 & 845.831 & 771.968 & 1.617 .799 \\
9 & 511.190 & 481.672 & 992.862 \\
10 & 391.628 & 524.260 & 915.888 \\
11 & 228.482 & 593.038 & 821.520 \\
12 & 201.447 & 673.443 & 874.890 \\
13 & 322.515 & 415.378 & 737.893 \\
14 & 381.901 & 487.710 & 869.611 \\
15 & 244.314 & 466.386 & 710.700 \\
16 & 199.034 & 163.786 & 362.821 \\
17 & 210.738 & 263.044 & 473.782 \\
\hline
\end{tabular}

\section{Analisis Dampak (Forward and Backward Linkage)}

Analisis Dampak keterkaitan antar sektor dapat dianalisis melalui penghitungan Indeks daya penyebaran (IBL) dan derajat kepekaan (IFL). Nilai Indeks daya penyebaran (IBL) dikenal dengan istilah lain yang biasanya disebut sebagai nilai indeks keterkaitan ke belakang (backward lingkages) sedangkan indeks derajat kepekaan (IFL) disebut dengan istilah lain sebagai indeks keterkaitan ke depan (forward lingkages). Berdasarkan hasil penghitugan IFL dan IBL maka dilakukan analisis kuadran untuk memetakan sektor dan mengidentifikasi sektor yang masuk ke dalam Lever sector. Kuadran I merupakan kuadran dengan karakteristik IBL dan IFL lebih dari satu, sektor yang masuk ke dalam kuadran ini merupakan sektor yang masuk atau diidentifikasi sebagai sektor penungkit atau unggul (Lever sector). Hal ini karena sektor dalam kuadran I mampu serta memiliki kemampuan yang besar dalam menggerakkan perekonomian baik dari segi sektor yang menjadi input maupun sektor yang memanfaatkan output sektor tersebut sehingga sektor yang masuk dalam kategori ini diklasifikasikan sebagai sektor yang unggul (mampu mengungkit perekonomian dengan baik). Sektor yang masuk dalam kategori ini adalah sektor ke-3 yaitu, Industri Pengolahan dan sektor ke-4 yaitu, Pengadaan Listrik, Gas.

Adapun kuadran II merupakan kuadran yang memuat sektor dengan nilai IBL $<1$ dan IFL $>1$, sektor yang masuk dalam kuadran ini mempunyai kemampuan menggerakkan (mengungkit) sektor yang menjadi input lebih rendah jika dibandingkan dengan rata-rata total perekonomian namun memiliki kemampuan penyerapan output oleh sektor lainnya yang tinggi di atas rata-rata total perekonomian. Dari hasil analisis, sektor yang masuk dalam kuadran ini sebanyak 3 sektor yaitu, sektor Pertanian, Kehutanan, dan Perikanan, sektor Pertambangan dan Penggalian dan sektor Jasa Perusahaan. Rendahnya nilai IBL ini dapat disebabkan oleh berbagai hal yaitu tingginya impor terhadap input antara yang memberi gambaran bahwa kekurangmampuan wilayah menyediakan faktor input untuk menghasilkan sektor tersebut. Kondisi seperti ini jelas kurang menguntungkan khusunya bagi ekonomi Indonesia. Apabila ekonomi Indonesia mengalami 
kenaikan permintaan, sektor yang masuk dalam kuadran ini dinilai kurang mampu memberikan nilai tambah khusunya bagi sektor-sektor yang menjadi input sektor tersebut. Akhirnya dengan adanya kondisi ini maka manfaat yang diterima apabila peningkatan permintaan terjadi adalah kecil bagi sektor-sektor lainnya.

Selanjutnya adalah kuadran III, sektor yang masuk kuadran ini menunjukkan nilai IFL dan IBL < 1 . Hal ni menunjukkan bahwa sektor ini kemampuan untuk menggerakkan atau mengungkit sektor yang menjadi input dan sektor yang memanfaatkan output sektor ini dibawah rata-rata total perekonomian sehingga sektor ini biasanya kurang diunggulkan. Sektor yang masuk dalam kuadran ini sebanyak 7 sektor yaitu, sektor ke$5,7,10,11,12,15$ dan 17. Sektor-sektor dalam kuadran III ini adalah sektor yang memiliki kemampuan untuk menggerakkan sektor penopang input maupun keluaran output yang digunakan untuk sektor kecil lainnya. Dari hasil analisis, sektor yang tercakup dalam kuadran ini merupakan sektor yang kurang unggul untuk dilakukan pengembangan lebih lanjut. Sektor-sektor yang termasuk kedalam kuadran ini menunjukkan masih rendahnya khusunya pada segi keterkaitan antar sektor yang menjadi input dengan sektor yang memanfaatkan output sektor tersebut.

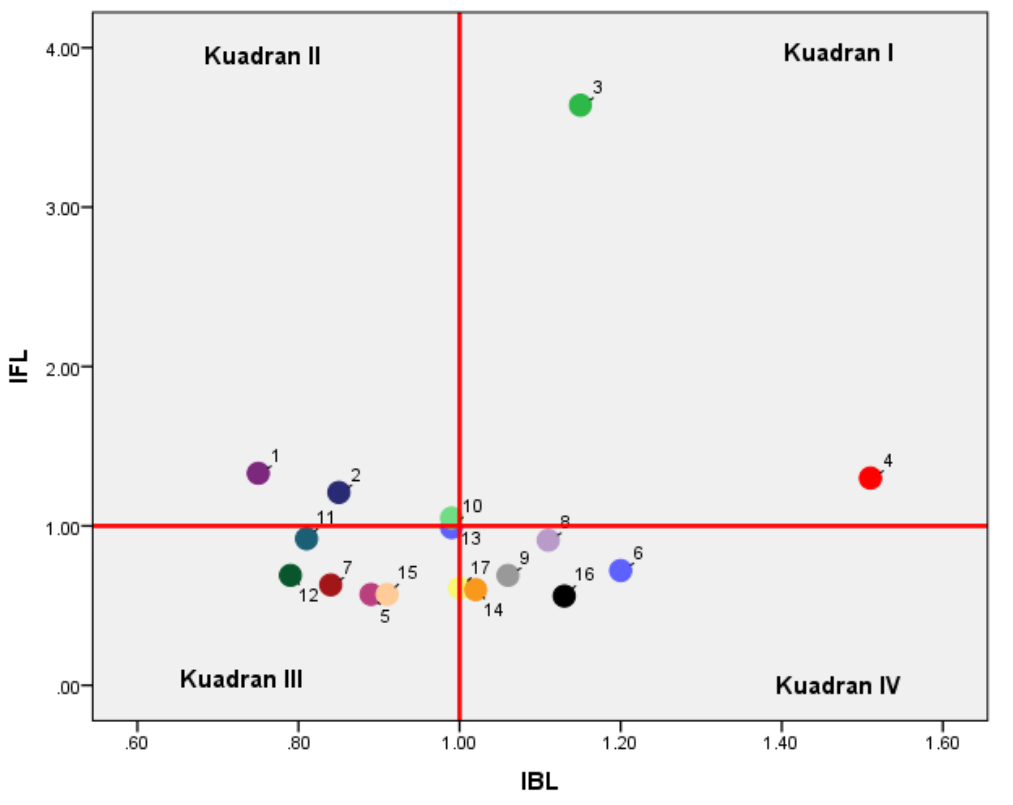

\author{
Keterangan : \\ 1: Pertanian, Kehutanan, dan Perikanan \\ 2: Pertambangan dan Penggalian \\ 3: Industri Pengolahan \\ 4: Pengadaan Listrik, Gas \\ 5: Pengadaan Air, Pengelolaan Sampah, \\ Limbah dan Daur Ulang \\ 6: Konstruksi \\ 7: Perdagangan Besar dan Eceran, \\ Reparasi Mobil dan Sepeda Motor \\ 8: Transportasi dan Pergudangan \\ 9: Penyediaan Akomodasi dan Makan \\ Minum \\ 10: Informasi dan Komunikasi \\ 11: Jasa Keuangan dan Asuransi \\ 12: Real estate \\ 13: Jasa Perusahaan \\ 14: Administrasi Pemerintahan, \\ Pertahanan dan Jaminan Sosial Wajib \\ 15: Jasa Pendidikan \\ 16: Jasa Kesehatan dan Kegiatan Sosial \\ 17: Jasa lainnya
}

Gambar 3. Analisis Kuadran IFL dan IBL, Table I-O 2020 yang diestimasi

Adapun kuadran IV menunjukkan sektor dengan IBL $>1$ dan IFL $<1$. Hal ini menunjukkan bahwa sektor ini memiliki kemampuan khususnya dalam menggerakan sektor dengan input diatas rata-rata total perekonomian. Di siis lain, kemampuan sektor yang memanfaatkan output dari sektor tersebut masih rendah dan dibawah rata-rata total perekonomian suatu wilayah. Pada Kuadran IV menunjukkan sebanyak 5 sektor yang masuk dalam kuadran ini yaitu, sektor ke-6,8,9,14 dan 16. Adapun sektor yang masuk dalam kuadran IV menunjukkan kemampuan keterkaitan kebelakang di atas rata-rata total seluruh perekonomian sehingga kondisi ini menjelaskan bahwa sektor dalam kuadran IV mampu menyerap berbagai input antara dalam suatu wilayah dengan sangat baik (cukup tinggi). Sektor yang tercakup pada kuadran ini masih sangat potensial untuk dikembangkan dengan karakteristik memiliki kekuatan untuk mendorong sektor-sektor yang menjadi suplai input lebih besar (backward linkagenya lebih besar kekuatannya dibandingkan dengan kekuatan forward linkagenya).

\section{Analisis Pengganda (Output, Income, Labor dan Value Added Multiplier}

Malba dan Taher (2016) menjelaskan output multiplier menunjukkan besaran dampak yang terjadi terhadap output manakala terjadi peningkatan permintaan akhir (baik dalam bentuk investasi atau lainnya) pada masing-masing sektor. Hasil penghitungan output multiplier yang ditunjukkan pada Tabel 3 menunjukkan bahwa sektor dengan besaran output multiplier terbesar adalah sektor ke-4 yaitu, sektor Pengadaan Listrik, Gas dan sektor dengan besaran output multiplier terkecil adalah sektor ke-1 yaitu, sektor Pertanian, Kehutanan, dan Perikanan. Adapun output multiplier untuk sektor 4 Pengadaan Listrik, Gas sebesar 2,86 yang menunjukkan permintaan akhir dari sektor ini meningkat sebesar satu juta rupiah maka output total seluruh sektor dalam ekonomi akan meningkat sebesar 2, 92 juta rupiah. 
Selanjutnya income multiplier menjelaskan besarnya dampak atau pengganda yang terjadi terhadap pendapatan ketika terjadi peningkatan pada permintaan akhir (baik dalam bentuk investasi ataupun lainnya) pada masing-masing sektor penyusun, yaitu 17 sektor lapangan usaha. Tidak jauh berbeda dengan output multiplier, besaran untuk income multiplier dengan nilai besaran paling tinggi adalah sektor 4 yaitu, Pengadaan Listrik, Gas dengan nilai sebesar 6,00. Hal ini menunjukkan apabila permintaan akhir dari sektor ini meningkat sebesar 1 juta rupiah maka pendapatan total dari seluruh sektor dalam ekonomi akan meningkat sebesar 6 juta rupiah. Di sisi lain sektor dengan nilai income multiplier terendah adalah sektor ke1 yaitu, sektor Pertanian, Kehutanan, dan Perikanan dan sektor ke-15 yaitu, sektor Jasa Pendidikan dengan nilai pengganda masing-masing sebesar 1,25.

Tabel 3. Hasil penghitungan IFL, IBL dan Analisis Pengganda

\begin{tabular}{ccccccc}
\hline Sektor & $\mathbf{I F L}$ & $\mathbf{I B L}$ & $\mathbf{O j}$ & $\mathbf{I j}$ & $\mathbf{L j}$ & $\mathbf{V j}$ \\
\hline 1 & 1,33 & 0,75 & 1,40 & 1,25 & 1,13 & 1,27 \\
2 & 1,21 & 0,85 & 1,63 & 1,66 & 2,80 & 1,43 \\
3 & 3,64 & 1,15 & 2,17 & 2,60 & 3,81 & 2,58 \\
4 & 1,30 & 1,51 & 2,86 & 6,00 & 8,01 & 4,56 \\
5 & 0,57 & 0,89 & 1,62 & 2,06 & 1,34 & 1,46 \\
6 & 0,72 & 1,20 & 2,23 & 2,16 & 3,05 & 2,56 \\
7 & 0,63 & 0,84 & 1,57 & 1,35 & 1,21 & 1,41 \\
8 & 0,91 & 1,11 & 2,11 & 2,18 & 2,23 & 2,10 \\
9 & 0,69 & 1,06 & 2,01 & 1,86 & 1,73 & 2,06 \\
10 & 0,99 & 0,99 & 1,72 & 1,90 & 3,43 & 1,75 \\
11 & 0,92 & 0,81 & 1,48 & 1,34 & 1,84 & 1,39 \\
12 & 0,69 & 0,79 & 1,45 & 2,39 & 4,24 & 1,30 \\
13 & 1,05 & 0,99 & 1,80 & 1,62 & 2,24 & 1,78 \\
14 & 0,60 & 1,02 & 1,90 & 1,41 & 1,72 & 1,78 \\
15 & 0,57 & 0,91 & 1,67 & 1,25 & 1,33 & 1,52 \\
16 & 0,56 & 1,13 & 2,00 & 1,79 & 1,83 & 2,22 \\
17 & 0,61 & 1,00 & 1,81 & 1,41 & 1,26 & 1,80 \\
\hline
\end{tabular}

Keterangan: label merah berarti nilai IFL atau IBL nya lebih dari 1, label hijau merupakan lever sector

Di sisi lain labor multiplier menjelaskan nilai dari besaran dampak yang ditimbulkan terhadap penyerapan tenaga kerja atau lapangan kerja apabila permintaan akhir mengalami peningkatan (baik dalam bentuk investasi atau lainnya) pada masing-masing sektor. Untuk labor multiplier dengan nilai tertinggi adalah sektor 4 yaitu, Pengadaan Listrik, Gas dengan nilai sebesar 8,01. Hal ini menunjukkan apabila permintaan akhir dari sektor ini meningkat sebesar 1 juta rupiah maka tenaga kerja yang diserap/lapangan pekerjaan dari seluruh sektor dalam ekonomi akan meningkat dengan menyerap 8-9 orang tenaga kerja. Adapun sektor dengan nilai labor multiplier terendah adalah sektor ke-1 yaitu, sektor Pertanian, Kehutanan, dan Perikanan dan sektor ke-7 yaitu, sektor Perdagangan Besar dan Eceran, Reparasi Mobil dan Sepeda Motor dengan nilai pengganda masing-masing sebesar 1,13 dan 1,21.

Value Added multiplier selanjutnya menggambarkan besaran angka sebagai dampak yang timbul terhadap peningkatan nilai tambah ketika permintaan akhir mengalami peningkatan (baik dalam bentuk investasi atau lainnya) pada masing-masing sektor. Untuk Value Added multiplier dengan nilai tertinggi adalah sektor 4 yaitu, Pengadaan Listrik, Gas dengan nilai sebesar 4,56. Hal ini menunjukkan apabila permintaan akhir dari sektor ini meningkat sebesar 1 juta rupiah nilai tambah dari seluruh sektor dalam ekonomi akan meningkat sebesar 4,56 juta rupiah. Adapun sektor dengan nilai Value Added multiplier terendah adalah sektor ke-1 yaitu, sektor Pertanian, Kehutanan, dan Perikanan dan sektor ke-12 yaitu, sektor Real Estat dengan nilai pengganda masing-masing sebesar 1,27 dan 1,30.

Hasil dari analisis pengganda sesuai dengan analisis dampak keterkaitan (IFL dan IBL) yang menunjukkan bahwa sektor dengan nilai IFL dan IBL yang tinggi juga memiliki nilai pengganda (multiplier effect) yang tinggi pula. Adapun sektor yang dapat diidentifikasi sebagai sektor pengungkit atau Lever sector dalam rangka pembangunan ekonomi di Indonesia adalah sektor ke-3 yaitu, Sektor Industri Pengolahan dan Sektor ke-4 yaitu, Sektor Pengadaan Listrik, Gas. Hasil ini jika dibandingkan dengan nilai struktur Tabel I-O sebelumnya menunjukkan sektor yang mempunyai share yang tinggi terhadap total ekonomi belum cukup bukti dan belum tentu dapat disebut sebagai sektor pengungkit atau Lever sector. 


\section{Diskusi: Sektor Pengungkit, Covid-19 dan Ekonomi Indonesia ke Depan}

Jika melihat hasil analisis secara angka memang sektor sektor ke-3 yaitu, Sektor Industri Pengolahan dan Sektor ke-4 yaitu, Sektor Pengadaan Listrik, Gas sebagai sektor pengungkit. Namun kita perlu melihat kembali terkait dengan besaran output, nilai tambah dan input dari masing-masing sektor. Dari kedua sektor ini, sektor yang memiliki struktur output paling besar adalah sektor industri manufaktur dengan share mencapai 28,86 persen dari total keseluruhan output sedangkan sektor listrik dan gas memiliki share kurang dari 3 persen. Hal ini menunjukkan bahwa sektor yang memiliki kekuatan pengungkit yang tinggi adalah sektor Industru Manufaktur. Di tengah kondisi Covid-19 yang memberikan dampak yang dahsyat pada berbagai sektor tidak terkecuali dengan sektor Industri Manufaktur mengharuskan pemerintah mengupayakan langkah strategis untuk menjaga lever power dari sektor ini.

Untuk mengupayakan pemulihan ekonomi Indonesia ke depan menerapkan berbagai kebijakan dan stimulus yang diluncurkan guna mengakselerasi pemulihan ekonomi nasional. Berbagai kebijakan dan stimulus yang diterapkan pemerintah untuk menjaga sektor ini tetap prima di masa pandemic Covid-19 adalah pembangunan kawaasan Industri. Sampai dengan saat ini, terdapat 128 kawasan industri yang sudah memiliki Izin Usaha Kawasan Industri dan telah beroperasi. Sementara itu, ada 38 kawasan industri yang saat ini masih dalam tahap konstruksi. Selain itu, Kementerian Perindustrian juga telah mengupayakan paeningkatan daya saing industri nasional melalui penerapan "Peta Jalan Making Indonesia". Program yang dilaksanakan ini sebagai upaya dalam pengembangan dan peningkatan tujuh sektor industri prioritas khususnya dalam mengimplementasikan teknologi digital pada proses produksinya sehingga diharapkan proses produksi yang dilaksanakan nantinya dapat efisien dan kompetitif. Adapun sektor-sektor yang menjadi prioritas tersebut antara lain, industri makanan dan minuman, kimia, tekstil dan pakaian, otomotif, elektronik, farmasi, serta alat kesehatan. Selain itu, pada sektor Industri Kecil Menengah (IKM), Kemenperin meluncurkan program e-Smart IKM untuk mendorong akselerasi penerapan teknologi industri 4.0 pada sektor manufaktur di tanah air. Di sisi lain, dari segi investasi global, Kemenperin juga mengupayakan keikutsertaan Indonesia sebagai partner country Hannover Messe 2021 untuk menarik investasi global dan perluasan pasar ekspor serta branding produk industri nasional. Kebijakan lainnya yang dilaksanakan oleh Kemenperin adalah program substitusi impor $35 \%$ pada tahun 2022, yang nantinya akan diimplementasikan secara simultan khususnya dengan peningkatan utilisasi produksi, mendorong pendalaman struktur industri, dan peningkatan investasi.

Guna menjalankan keberlangsungan usaha di masa pandemic Covid-19, lebih lanjut Menteri Perindustrian Agus Gumiwang Kartasasmita memberikan langkah strategis bagi pelaku usaha yaitu 5R :

a. Resolve atau menangani pandemi di lingkungan perusahaan, termasuk dengan melibatkan partisipasi karyawan dalam penerapan protokol kesehatan.

b. Resilience atau upaya memperkuat perusahaan sehingga dapat bertahan

c. Return atau kembali menjalankan aktivitas dengan mempertimbangkan aspek-aspek yang penting bagi masing-masing perusahaan

d. Re-Imagination atau perusahaan perlu kembali memetakan bisnisnya berdasarkan kondisi baru yang dihadapi

e. Reform atau mereformasi model bisnis untuk mengambil peluang. Misalnya dengan mempertimbangkan opsi-opsi peluang bisnis baru dan menerapkan metode baru dalam bekerja untuk mengakselerasi produktivitas dengan memanfaatkan teknologi terkini.

harapannya dengan berbagai kebijakan dan stimulus yang dilakukan perekonomian Indonesia mengalami pemulihan secara bertahap.

\section{KESIMPULAN}

Setelah dilakukan penghitungan dan estimasi untuk menghasilkan Tabel I-O Tahun 2020 dengan menggunakan indikator-indikator ekonomi yang ada maka dari hasil analisis dampak keterkaitan (forward and backward linkage) dan analisis pengganda dapat disimpulkan bahwa sektor industri pengolahan (sektor 3) dan pengadaan listrik, sektor gas (sektor 4) diidentifikasi sebagai Lever sector atau sektor pengungkit. Namun, setelah ditinjau lebih lanjut sektor yang memiliki lever power paling tinggi adalah sektor Industri pengolahan atau industri manufaktur. Jadi sektor inilah yang menjadi tumpuan dan sektor pengungkit yang dapat membantu memulihkan ekonomi Indonesia karena outputnya yang besar. Selain itu, sektor ini berdasarkan hasil forward linkage (IFL) dan backward linkage (IBL) memiliki nilai lebih dari 1. Sejalan dengan analisis keterkaitan, analisis multiplier dari 4 pendekatan yang berbeda menunjukkan bahwa sektor ini memiliki nilai pengganda yang paling besar. 


\section{SARAN}

Selain itu, saran dari penelitian ini adalah pemerintah harus memperhatikan industri manufaktur dari sisi konsumsi menengah. Pemerintah dapat meningkatkan output industri pengolahan dengan memberikan subsidi atau menurunkan pajak. Pemerintah dapat menurunkan harga sektor lain yang menjadi sektor perantara (input antara) bagi industri pengolahan dengan memberikan subsidi. Cara ini dapat meningkatkan output industri pengolahan yang juga meningkatkan output sektor lain. Selanjutnya, pemerintah harus memperhatikan pasokan listrik dan gas dari sisi permintaan input. Pemerintah dapat menurunkan harga sektor ini dengan memberikan subsidi sehingga sektor lain dapat memberikan nilai tambah yang lebih tinggi pada share PDB. Peningkatan kapasitas listrik melalui energi terbarukan juga perlu dilakukan pemerintah untuk menghasilkan energi listrik yang cukup dan ramah lingkungan.

\section{DAFTAR PUSTAKA}

Amir, H \& Nazara, S. (2005). Analisis Perubahan Struktur Ekonomi (Economic Landscape) dan Kebijakan Strategi Pembangunan Jawa Timur Tahun 1994 dan 2000 : Analisis Input-Output.

Badan Pusat Statistik. (2015). Tabel Input Output Indonesia 2010. Jakarta : BPS, Indonesia.

Badan Pusat Statistik. (2021). Tabel Input Output Indonesia 2016. Jakarta : BPS, Indonesia.

Dunford, M. (2009). Regional Development Models. International Encyclopedia of Human Geography, 12(1), 192-201.

Malba, E \& Taher, IM. (2016). Analisis Input-Output Atas Dampak Sektor Pariwisata Terhadap Perekonomian Maluku. Jurnal Bina Ekonomi Vol.20 (2) : hal 213-229.

Pribadhi, B. (2019). Analisis Dampak Komoditas Padi Terhadap Perekonomian Jawa Timur : Pendekatan Input Output. Skripsi Universitas Jember, Jember, $60 \mathrm{hlm}$.

Sapanli et al. (2020). Dinamika dan Kebijakan Pengembangan Ekonomi Kelautan Indonesia. Jurnal Kebijakan Sosek KP Vol.10 (2) : hal 117-129.

Todaro, M \& Smith, S. (2011). Ekonomi Pembangunan di Dunia Ketiga. Jakarta : Erlangga.

United Nations (UN). (1999). Handbook of Input-Output Table Compilation and Analysis. Department of Economics and Social Affairs, Division of Statistics, New York.

Widyawati, RF. (2017). Analisis Keterkaitan Sektor Pertanian dan Pengaruhnya Terhadap Perekonomian Indonesia (Analisis Input Output). Jurnal Economia, Vol.13 (1) : 14-27. 